\title{
DESIGN, SIMULATION AND IMPLEMENTATION OF MPPT CONTROLLED BUCK-BOOST CONVERTER EXTRACTING POWER FROM SOLAR PANEL FOR MICROGRID APPLICATIONS
}

\author{
Pooja Ainapure, Pranav Kulkarni, Swapnil U. Patil, Atul Tiwari \\ Department of Electrical Engineering, \\ College of Engineering, Pune, India
}

\begin{abstract}
The work is dedicated to implementation of $D C-D C$ converter for $P V$ system in medium power Microgrid applications. Due to availability of flexible power management strategies along with effective cost, micro-grids are gaining immense popularity in present days. DC Microgrid mainly consists of PV system and battery system. Battery system plays very important role in improving dynamic response of the Microgrid. While designing power modulators for DC storage system, efficiency is a major concern. This paper proposes a method for modeling, simulation and hardware implementation of PV system and maximum power point tracking using Buck-Boost converter. Since PV cells have poor efficiency it is necessary to operate them at maximum power point using incremental conductance. The converter topology used here is Modified Buck-Boost Converter. All the simulations were carried out on $M A T L A B$ using variable parameters and the hardware results were verified on the PV arrays along with $P V$ panel simulator.
\end{abstract}

Keywords: Buck-boost converter, Incremental conductance algorithm, Maximum power point tracking, $\mathrm{PnO}$ algorithm, PV system

Cite this Article: Pooja Ainapure, Pranav Kulkarni, Swapnil U. Patil and Atul Tiwari, Design, Simulation and Implementation of MPPT Controlled Buck-Boost Converter Extracting Power from Solar Panel for Microgrid Applications, International Journal of Electrical Engineering \& Technology, 10(6), 2019, pp. 1-11.

http://iaeme.com/Home/issue/IJEET?Volume=10\&Issue $=6$

\section{INTRODUCTION}

With the help of renewable sources like wind, solar along with the help of distributed generation system, effective power efficient and fairly reliable system can be established in the form of Microgrid. In order to satisfy the demand of DC load especially in DC Microgrid many sources are operating in parallel to supply power. Solar power plants, battery storage

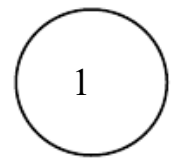


systems are connected to DC bus via DC-DC converters. Solar PV is the main source of the energy in the system.[1][2] There are two main problems associated with the PV systems; one is the efficiency of conversion is very low $10 \%-17 \%$. The change in the climatic conditions affects the irradiance and thus the solar power generated is also affected.

Secondly, the non-linearity of the V-I characteristics of solar panel makes the job difficult. It changes with the change in irradiance and temperature. To address this problem, On the V-I graph there is one point called maximum power point (MPP) where the power delivered is maximum. This point is tracked by search algorithms. Analysis of various algorithms is done and incremental conductance ( $\mathrm{InC}$ ) method is chosen for implementation because of the precise control under changing weather conditions and no oscillation around MPP and power loss due to oscillations at MPP is reduced [2][3]. The converter used is modified Buck-Boost converter. The factors leading to the DC-DC buck converter design are also discussed. Since most of the DC loads are operated at $48 \mathrm{~V}$ it is wise to use Buck mode. But in case of partial shading, voltage of PV panel may fall below certain limit so it is advisable to boost mode. It gives us the control as which mode to use depending on the weather conditions. In this work first the mathematical model of PV panel was studied and developed in the MATLAB [4]. Next the converter simulation was completed and InC algorithm was tested for buck and boost mode. The mode shifting was also verified in simulation. The simulation results were verified with the solar panel simulator of TERASAS and further the algorithm and converter were tested on actual PV panels.

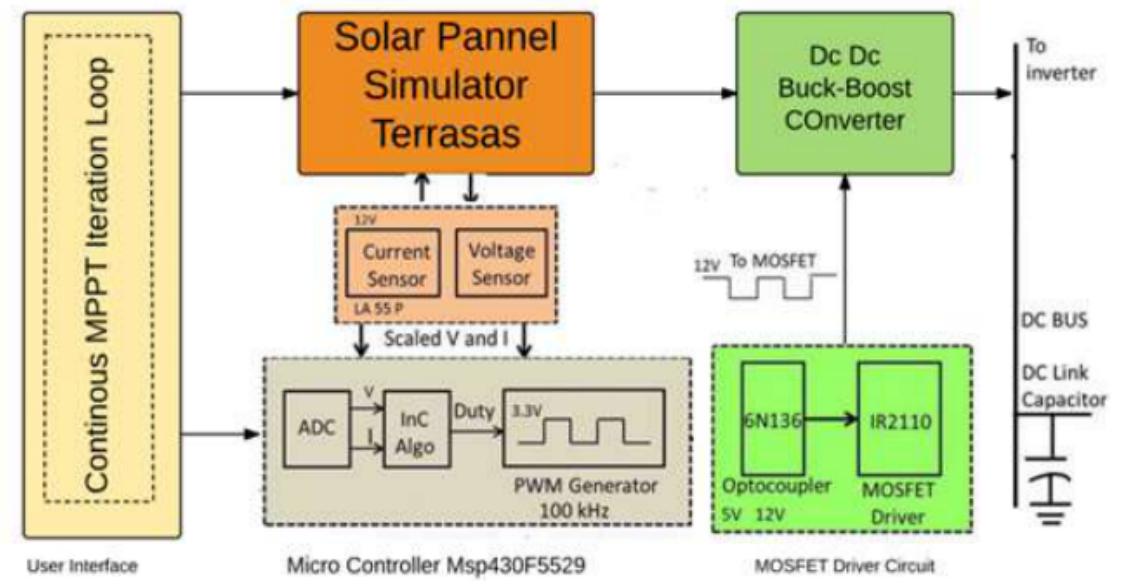

Figure 1.1 block diagram of overall system

\section{MATHEMATICAL MODELLING OF PV PANEL AND SIMULATION}

A solar panel is an array of solar cells arranged in series and parallel so as to obtain the desired current and voltage. The output of solar panel is nonlinear following a distinct currentvoltage characteristic which varies according to the existing temperature, irradiance conditions also the load connected, the operating point varies accordingly. Modelling this device necessarily requires taking weather data (irradiance and temperature) as input variables and the output is non-linear V-I characteristics [2][5]. Any change in the input immediately changes the output, so we have to model the system correctly. A solar panel is thus simulated in MATLAB SIMULINK as in Fig(2.4). The panel is simulated with the help of the following equations [4] .Here we have considered the Single-Diode model of Photovoltaic cell as shown in Fig 2.1 . 
Design, Simulation and Implementation of MPPT Controlled Buck-Boost Converter Extracting Power from Solar Panel for Microgrid Applications

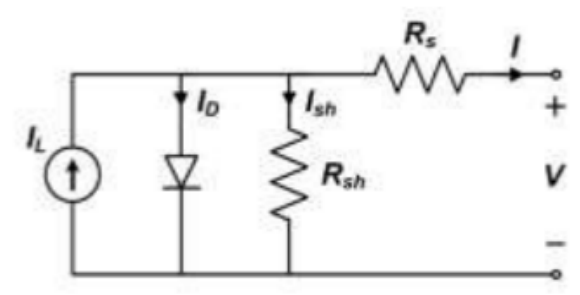

Figure 2.1 Single diode model of PV cell

$R_{\text {sh }}$ and $R_{s}$ are the shunt and series resistance and $I_{\text {sh }}$ is Shunt current.

The panel is simulated with the help of following equations:

Thermal Voltage Equation:

$\mathrm{V}_{\mathrm{T}}=\frac{\mathrm{k}_{\mathrm{B}} \times \mathrm{T}_{\mathrm{opt}}}{\mathrm{q}}$

Diode current equation:

$$
I_{D}=N_{p} \times I_{S}\left[e^{\frac{\left(\frac{V+I_{S}}{N_{S}}\right)}{N_{T} \mathrm{C}}}-1\right]
$$

Reverse current equation:

$$
I_{R S}=\frac{I_{S C}}{e^{\left[\frac{q \times V_{o c}}{\mathrm{~K}_{\mathrm{B} \times{ }^{\mathrm{T}} \mathrm{opt} \times \mathrm{C} \times \mathrm{N}}}-1\right]}}
$$

Photo current equation:

$$
\mathrm{I}_{\mathrm{ph}}=\left[\mathrm{k}_{\mathrm{i}}\left(\mathrm{T}_{\mathrm{opt}}-\mathrm{T}_{\mathrm{ref}}\right)+\mathrm{I}_{\mathrm{sc}}\right] \mathrm{I}_{\mathrm{RR}}
$$

Reverse saturation current equation:

$$
I_{S}=I_{R S}\left[\frac{T_{o p t}}{T_{\text {ref }}}\right]^{3} \times q^{2} \times \frac{E_{g}}{k_{B} \times N} \times e^{\left[\frac{1}{T_{\text {opt }}}-\frac{1}{T_{\text {ref }}}\right]}
$$

Table 1 Constants and abbreviations used for PV panel modelling

\begin{tabular}{|c|l|c|l|}
\hline $\mathrm{V}_{\mathrm{T}}$ & thermal voltage $(\mathrm{V})$ & $\mathrm{I}_{\mathrm{s}}$ & Reverse saturation current of diode \\
\hline $\mathrm{k}_{\mathrm{B}}$ & Boltzmann constant $\left(1.38 \times 10^{-23} \mathrm{~J} / \mathrm{K}\right)$ & $\mathrm{I}_{\mathrm{sc}}$ & Short circuit current \\
\hline $\mathrm{C}$ & cells in module & $\mathrm{I}$ & Cell output current \\
\hline $\mathrm{T}_{\text {ref }}$ & $\begin{array}{l}\text { reference operating temperature of } \\
\text { cell }(298 \mathrm{~K})\end{array}$ & $\mathrm{I}_{\mathrm{ph}}$ & $\begin{array}{l}\text { photocurrent function of irradiance and } \\
\text { temperature }\end{array}$ \\
\hline $\mathrm{k}_{\mathrm{i}}$ & current proportionality constant $\left(2.2 \times 10^{-3}\right)$ & $\mathrm{I}_{\mathrm{D}}$ & Diode Current \\
\hline $\mathrm{T}_{\mathrm{opt}}$ & operating temperature of cell & $\mathrm{I}_{\mathrm{RS}}$ & Reverse current equation \\
\hline $\mathrm{N}$ & ideality factor & $\mathrm{I}_{\mathrm{RR}}$ & Irradiance factor \\
\hline $\mathrm{N}_{\mathrm{s}}$ & no. of cells in series & $\mathrm{N}_{\mathrm{p}}$ & no. of cells in parallel \\
\hline
\end{tabular}


Pooja Ainapure, Pranav Kulkarni, Swapnil U. Patil and Atul Tiwari

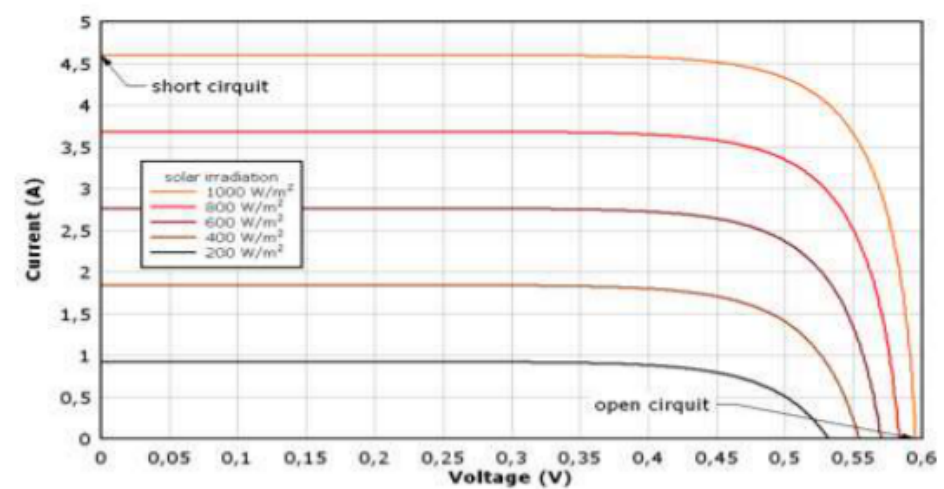

Figure. 2.2 VI characteristics of PV panel for varying Irradiance

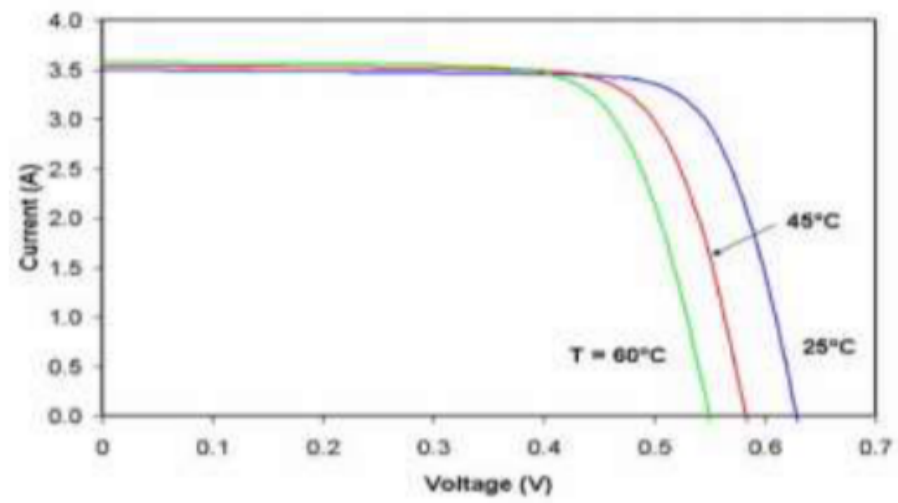

Figure 2.3 VI characteristics of PV panel for varying temperature

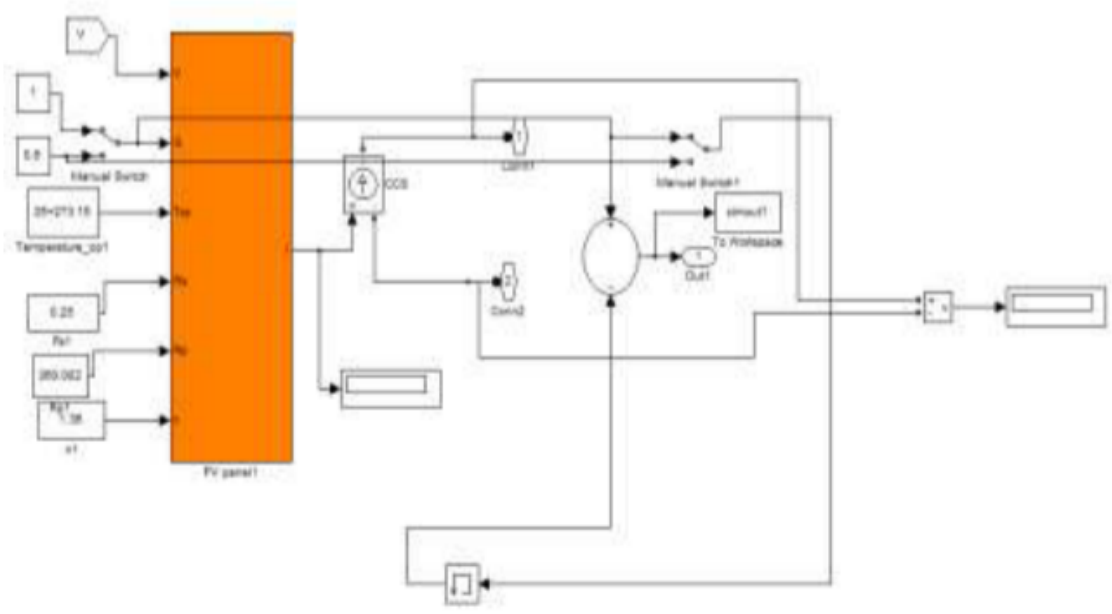

Figure 2.4 PV panel simulated in MATLAB

\section{MPPT ALGORITHM}

The MPPT is an electronic system that operates the PV modules in such a way that it allows the modules to produce all the power they are capable of it. It is done by various algorithms like fractional open circuit voltage or short circuit current, Perturb and Observe (PnO), Incremental Conductance (InC), Fuzzy Logic etc [2][5][6]. Here we are using InC algorithm because of its efficient work in varying weather conditions, better than $\mathrm{PnO}$ and less complicated than Fuzzy logic 


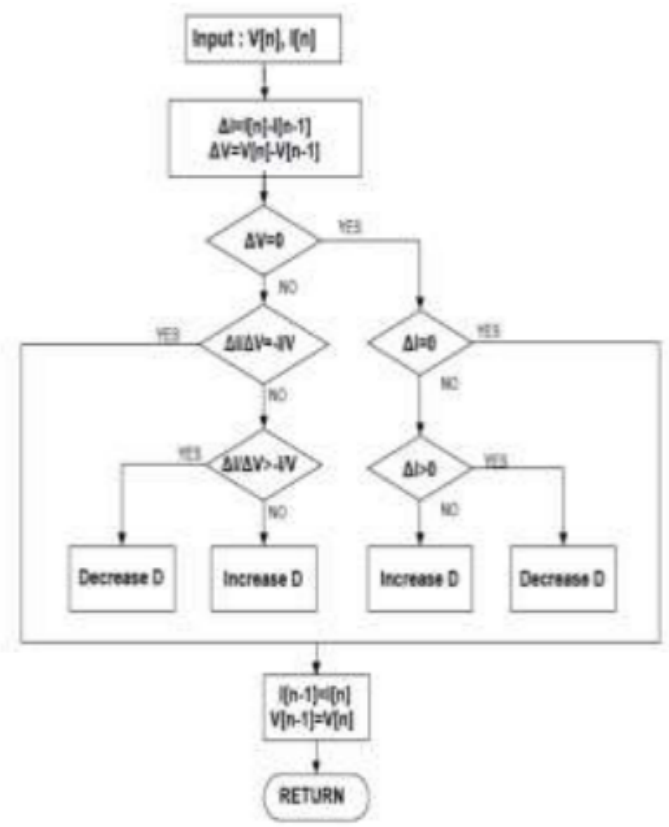

The following equations govern the Incremental Conductance algorithm

$$
\begin{gathered}
\frac{d P}{d V}=\frac{d(V I)}{d V}=I+V \frac{d I}{d V}=0 \quad \text { at MPP } \\
\frac{d I}{d V}=-\frac{I}{V}
\end{gathered}
$$

\section{SYSTEM DESIGNING AND COMPONENT SELECTION}

In order to convert the power available at the panel output to suitable form DC-DC converters are required. There are various converter topologies like Buck, Buck-Boost, Cuk, Sepic converter [7]. By considering pros and cons of the every converter topology it is observed that Buck-Boost have following advantages over other topologies.

- Simple in construction

- Small values of $\mathrm{L}$ and $\mathrm{C}$ required for given operation

- Less settling time

- Output is not inverted

The converter used is a modified Buck-Boost converter so that the output voltage polarity is not reversed. It consists of two MOSFETs, two freewheeling Diodes, one inductor and two capacitors for input and output.

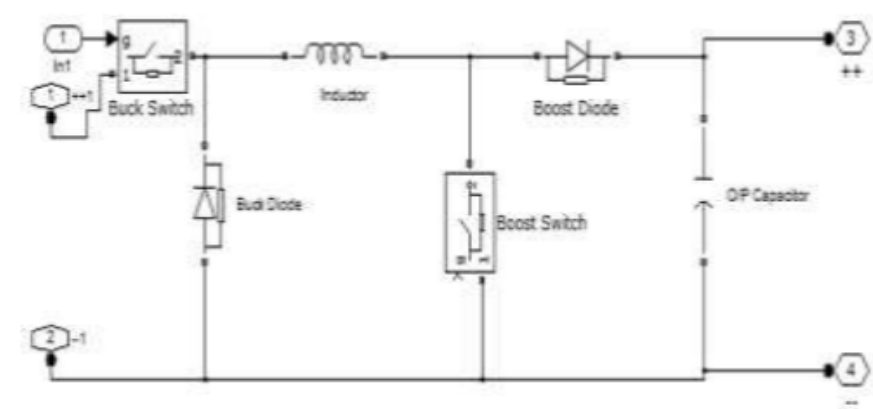

Figure 4.1: Schematic of Buck-boost converter 
The switching frequency used for both MOSFETs is $100 \mathrm{kHz}$. It brings down the values of the Inductor and Capacitor, so the circuit becomes less bulky. The converter operates in one mode at a time. If it is buck then normal buck equations hold and if it is boost normal boost equation holds [8].

$$
\begin{aligned}
& \text { Vout }=\mathrm{D} * \text { Vin } \\
& \text { Vout }=\frac{\text { Vin }}{1-\mathrm{D}}
\end{aligned}
$$

Boost equation

\subsection{Design Specification}

- Short circuit current of panel : 3 Ampere

- Maximum voltage at MPP : 16.25 Volt

- Open circuit voltage of panel : 19.12 Volt

Let's assume efficiency of converter is $80 \%$ hence to achieve output power of 500 Watts min, required input power will be 643 Watts. We have fixed output voltage of converter to 48 V.

$$
\mathrm{I}_{\max }=\frac{514.4}{48}=10.716 \mathrm{~A} \max
$$

\subsection{Sizing of Inductors and Capacitors}

Inductor: $\mathrm{V}_{\text {in (min) }}=60 \mathrm{~V}$ and $\mathrm{V}_{\text {in (max) }}=130 \mathrm{~V}$

Assuming MOSFET voltage drop across it as 0.3 Volt

$$
\begin{aligned}
\mathrm{D}_{\text {max }} & =\frac{\mathrm{V}_{\text {out }}}{\mathrm{V}_{\text {in(min) }}-\mathrm{V}_{\text {mosfet }}} \\
& =\frac{48}{60-0.3}=0.8 \\
\mathrm{D}_{\text {min }} & =\frac{\mathrm{V}_{\text {out }}}{\mathrm{V}_{\text {in(max) }}-\mathrm{V}_{\text {mosfet }}} \\
& =\frac{48}{130-0.3}=0.37 \\
\mathrm{dI}(\text { ripple current }) & =0.2 \times \mathrm{I}_{\text {out }} \\
& =0.2 \times 10.716=2.1432 \mathrm{~A}
\end{aligned}
$$

$\mathrm{dV}($ output voltage ripple $)=300 \mathrm{mV}$

$$
\begin{aligned}
\mathrm{L}(\text { inductor value }) & =\frac{\left(\mathrm{V}_{\mathrm{in}(\min )}-\mathrm{V}_{\text {out }}\right) \times \mathrm{D}_{\max }}{\mathrm{dI} \times \mathrm{f}} \\
& =\frac{(60-48) \times 0.8}{2.1432 \times 10^{5}}=0.04479 \mathrm{mH}
\end{aligned}
$$

The calculations of inductance and capacitance are done for the largest range so as to get largest value as possible. The switching device used is MOSFET IRFP $250 \mathrm{~N}$ having $\mathrm{V}_{\mathrm{ds}}$ of $200 \mathrm{~V}$ and pulsed drain current of $30 \mathrm{~A}$. As the switching frequency is $100 \mathrm{kHz}$ so as to minimize loss in energy storing components, but at the same time recovery period is expected to be very less and hence diode used is fast recovery diode. The fast recovery diode used is MUR3060 having peak reverse voltage rating of $1200 \mathrm{~V}$ and a recovery time of $85 \mathrm{~ns}$.

For MPPT algorithm sensor needs to be very precise and accurate. Therefore current sensor used is ACS721 having sensitivity of $185 \mathrm{mV} / \mathrm{A}$ and current measuring range from -5 A to $5 \mathrm{~A}$. The output of sensor in form of voltage is given to ADC of the microcontroller. 
Similarly for voltage sensing isolated voltage signal is obtained by potential divider arrangement which applied to ISO $124 \mathrm{U}$ which is unity gain IC whose output is given to ADC of microcontroller.

\subsection{Microcontroller and Driver for Switching Application}

The driver circuit is used to drive the MOSFET switch at threshold voltage. The Buck-Boost converter have both high side and low side switches. Hence this circuit consists of an optocoupler 6N136, driver IC IR2110. The isolation of the microcontroller from the power circuit is provided by the opto-coupler.The microcontroller used is Texas Instruments MSP 430F5529. It has a clock frequency of $25 \mathrm{MHz}$ which makes PWM control more precise. It has 5 ePWM channels and 16 ADC channels. The programming is done through Code Composer Studio.
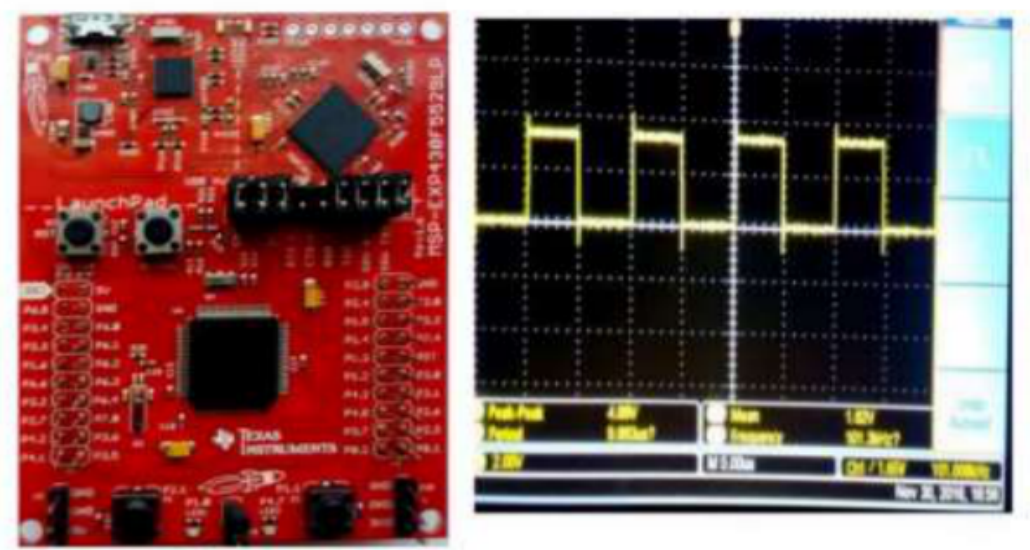

Figure 4.2 MSP 430F5529 and waveform observed on DSO

\section{SIMULATION RESULTS}

The first simulation was carried out with mathematical model of PV having open circuit voltage as $100 \mathrm{~V}$ and short circuit current as $10 \mathrm{~A}$ and constant irradiance of $1000 \mathrm{~W} / \mathrm{sq}$. m and constant resistive load of 2 Ohms [1][6].

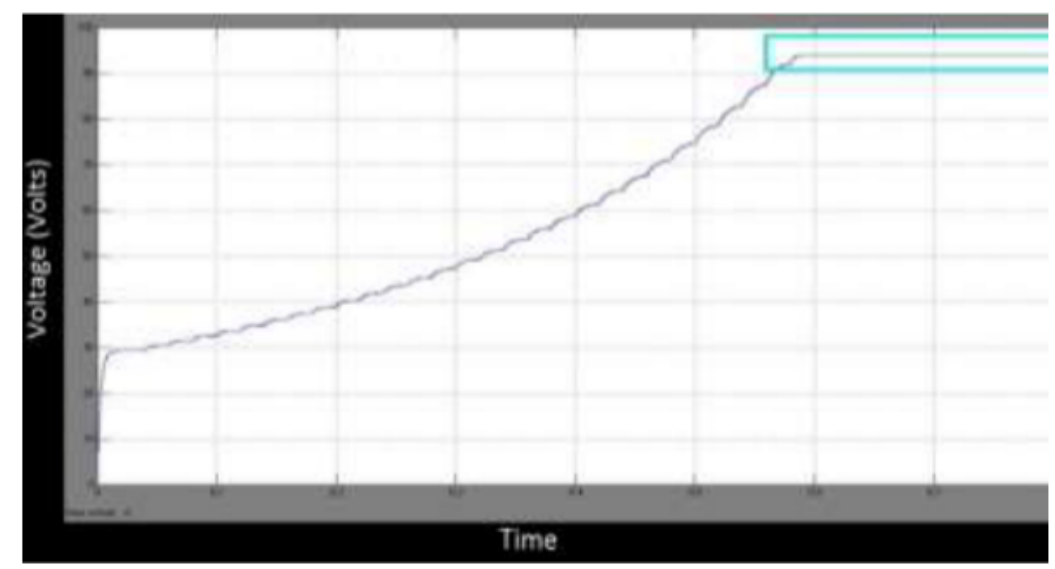

Figure 5.1 Voltage waveform for constant resistive load and constant irradiance 


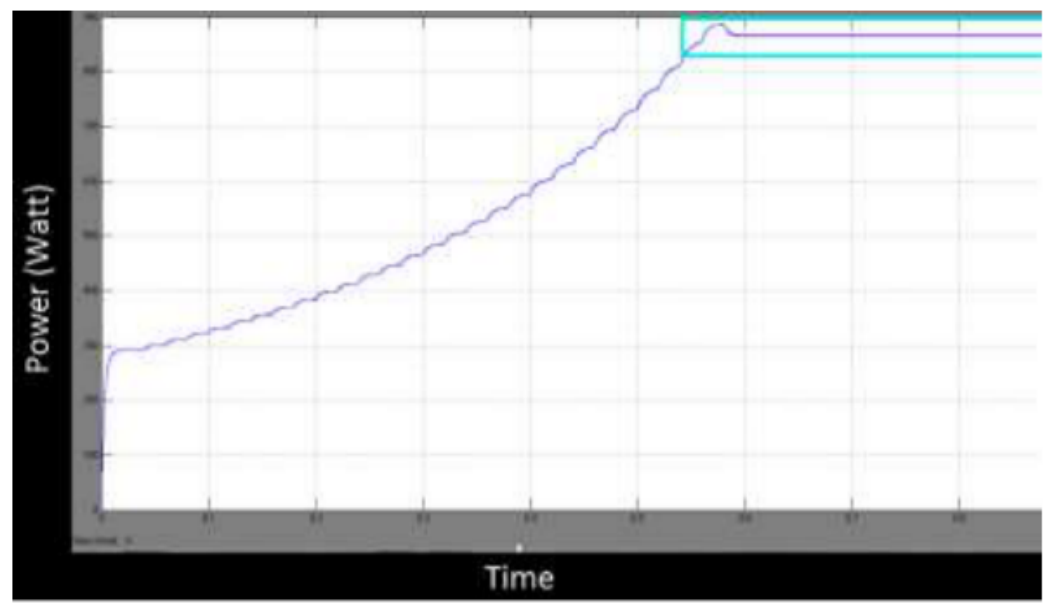

Figure 5.2 Power waveform for constant resistive load and constant irradiance

The second simulation was carried out with changing irradiance from $1000 \mathrm{~W} / \mathrm{sq} \mathrm{m}$ to $600 \mathrm{~W} / \mathrm{sq} \mathrm{m}$

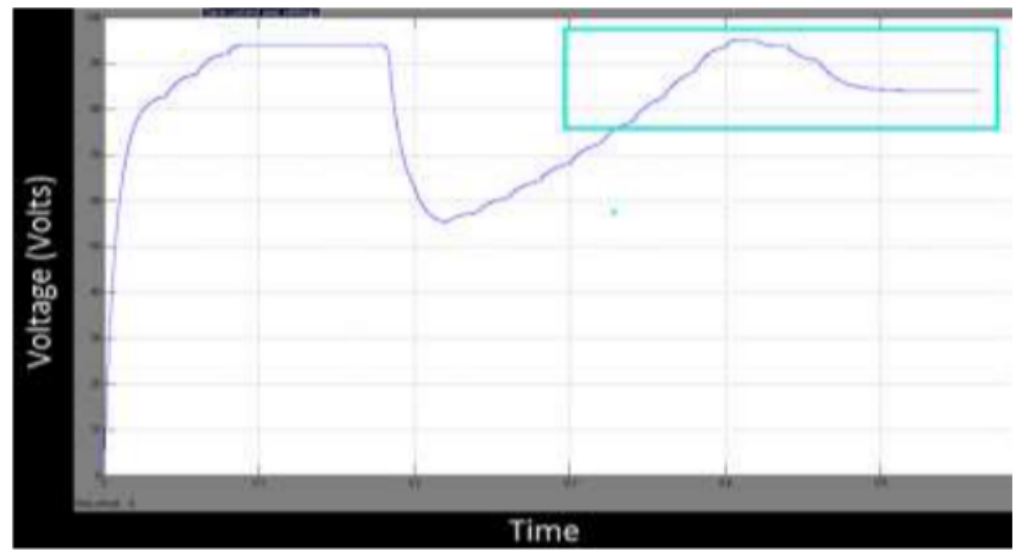

Figure 5.3: Voltage waveform for constant resistive load and changing irradiance

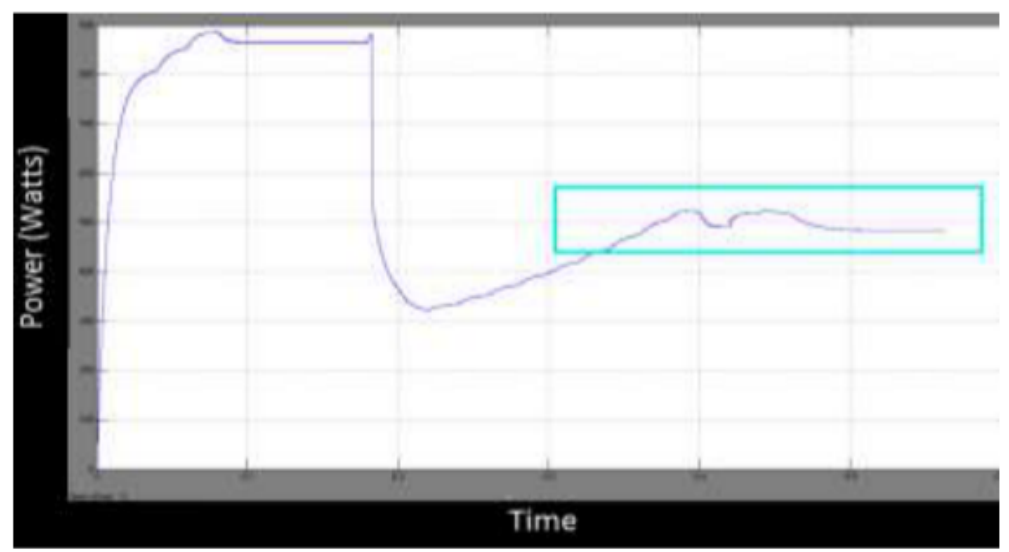

Fig 5.4: Power waveform for constant resistive load and changing irradiance

\section{HARDWARE IMPLEMENTATION}

Before going to the testing on actual solar panels, the MPPT algorithm was verified and hardware was tested on the solar panel simulator. The Elgar PV simulator is a programmable digital power source designed to simulate the electrical behaviour of terrestrial photovoltaic arrays [8]. The simulator provides a turnkey hardware and software solution to deliver all functionality required to test the MPPT characteristics. It is controllable through a PC. It uses 
LAN as a communication protocol. All the hardware components like driver circuit, sensors, and converter are firstly designed in PCB design software and later printed on PCB. The microcontroller is initially burned with the program from Code Composer Studio. Then various VI curves loaded via visual interface to the simulator, while in runtime, the ultimate control over the entire system is governed by GUI.

The sequential flow of the MPPT system runs as shown in Fig.6.1. Initially curve of particular open circuit voltage and short-circuit current is loaded. The power supply for power circuit as well as for auxiliaries is initialized. Initially duty ratio is set to $40 \%$ and ADCs are initiated. For higher accuracy the ADCs are sampled a number of times and for stable value and higher accuracy average of samples is consider for the Incremental conductance algorithm. By following the algorithm the duty cycle is calculated and changed accordingly. For the next iteration voltage and current changed accordingly as per changed in output impedance seen by the converter and this is how cycle continues.

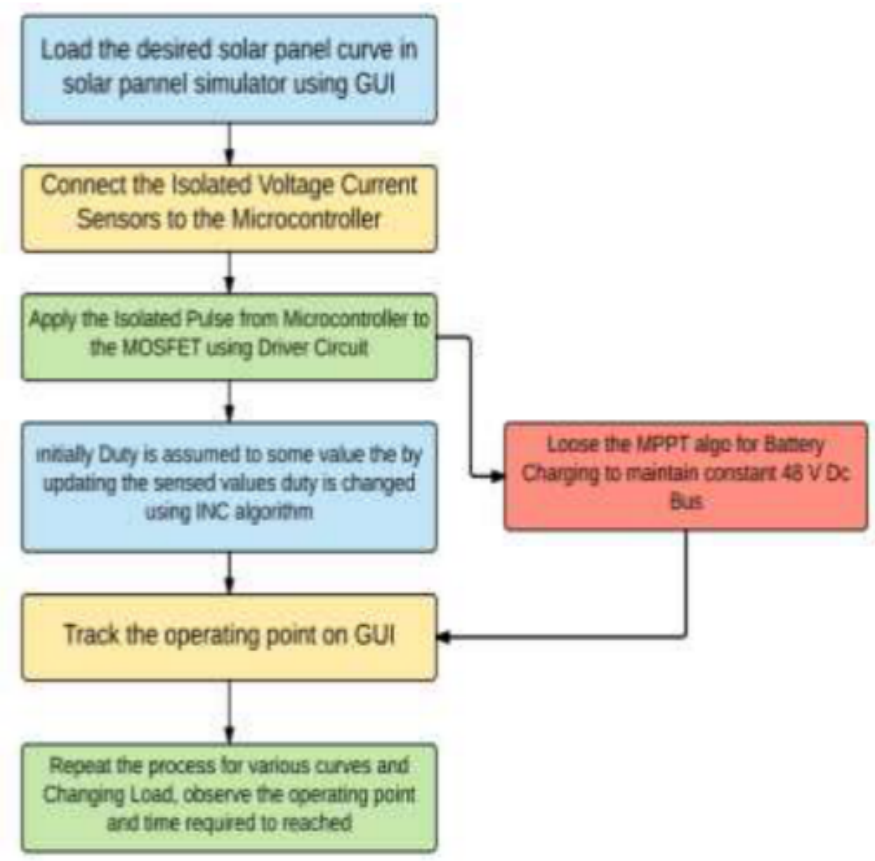

Figure 6.1 Sequential flow of MPPT system

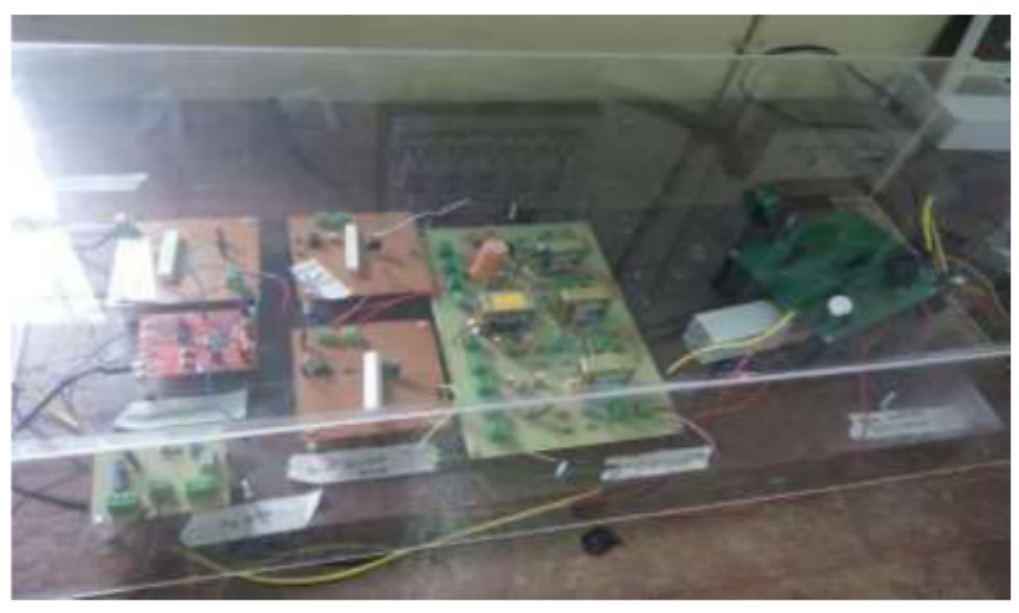

Figure 6.2 Hardware implementation of MPPT converter 


\section{RESULTS}

The MPPT algorithm was successfully tested and verified on the solar panel simulator with changing irradiance and variable load. The following results were obtained for fixed load and variable curve $\left(\mathrm{V}_{\mathrm{oc}}\right.$ and $\mathrm{I}_{\mathrm{sc}}$ variable). After that the system was tested on actual solar panels. As per the availability of solar panel 5 panel were connected in series having total open circuit voltage as $92.1 \mathrm{~V}$ and short circuit current was $3 \mathrm{~A}$. The MPPT algorithm was successfully tested with $\mathrm{V}_{\text {mpp }}$ as $72 \mathrm{~V}$ and $\mathrm{I}_{\mathrm{mpp}}$ as $2.96 \mathrm{~A}$. Fig 7.1 shows that for a particular open circuit voltage and short circuit current, maximum power point achieved. And by changing input we can affirmed the accuracy and proper working of converter at MPP.

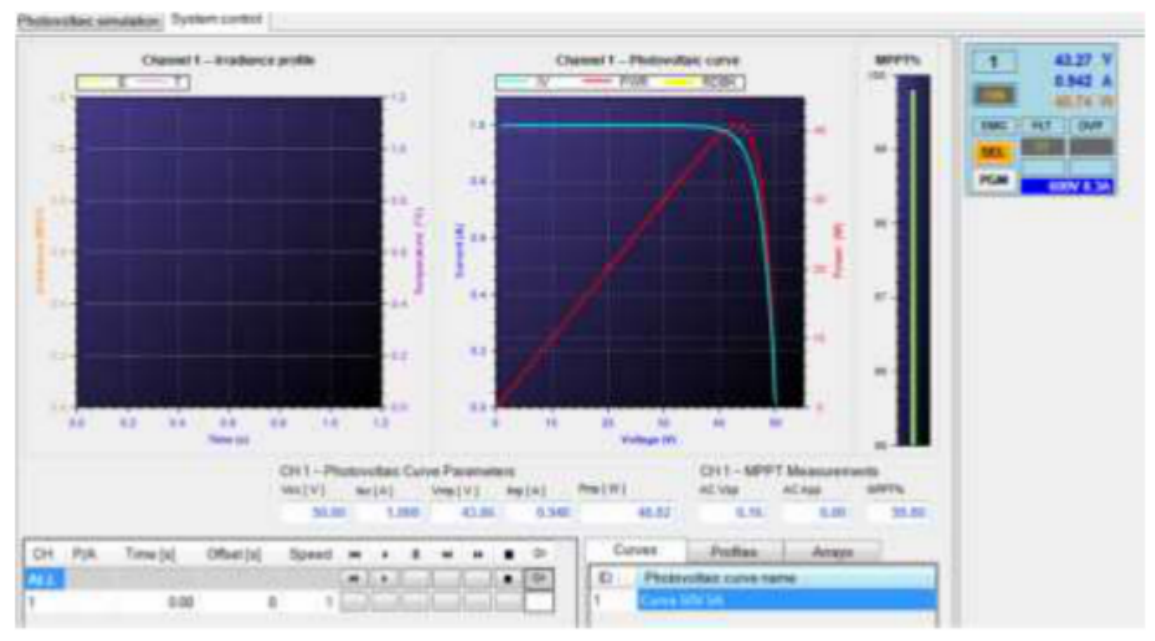

Figure 7.1 Visual interface for tracking MPP

Table 2 Output for changing curves obtained by simulator

\begin{tabular}{ccccccc}
\hline No & $\begin{array}{c}\text { Output } \\
\text { voltage(V) }\end{array}$ & $\begin{array}{c}\text { Output } \\
\text { current(A) }\end{array}$ & Power(W) & $\begin{array}{c}\text { Input } \\
\text { voltage }\end{array}$ & $\begin{array}{c}\text { Input } \\
\text { current }\end{array}$ & Efficiency (\%) \\
\hline 1 & 85.3 & 5.45 & 464.885 & 88.39 & 5.49 & 95.8 \\
\hline 2 & 80.4 & 5.77 & 463.9 & 88.39 & 5.49 & 95.5 \\
\hline 3 & 76.4 & 5.85 & 446.94 & 88.39 & 5.49 & 92.1 \\
\hline 4 & 73.4 & 5.97 & 438.2 & 88.39 & 5.49 & 90.4 \\
\hline 5 & 70.2 & 6.07 & 426.11 & 88.39 & 5.49 & 87.81 \\
\hline 6 & 50 & 7.15 & 358.95 & 88.39 & 5.49 & 74.01 \\
\hline 7 & 45.3 & 7.58 & 343.37 & 88.39 & 5.49 & 70.8 \\
\hline
\end{tabular}

\section{CONCLUSION}

The approach presented in this paper is to work efficiently for simulated conditions. Intricacies of solar panel, DC-DC converters, MPPT algorithm were analysed, designed and implemented. The system was tested at steady power output of $600 \mathrm{~W}$ using solar panel simulator and up to $300 \mathrm{~W}$ using solar panels working satisfactorily for changing irradiance conditions. The future scope will include to make system more robust, to provide cooling system for MOSFET and to increase the speed of operation by using high precision sensors. On a clearer and specific knowledge of working conditions, more complex algorithms of fuzzy logic based MPPT, neural networks etc. can be studied and implemented on this system. 
Design, Simulation and Implementation of MPPT Controlled Buck-Boost Converter Extracting Power from Solar Panel for Microgrid Applications

\section{REFERENCES}

[1] Key-Hsiang Chao, Ming-Chang Tseng, "Design and Implementation of a bidirectional DC-DC converter for stand-Alone Photovoltaic systems", International Journal of Computer, Consumer and Control (IJ3C), Vol. 2, No.3 (2013)

[2] Mohamed A. Eltawil, Zhengming Zhao, "MPPT Techniques for photovoltaic applications", Renewable and Sustainable Energy Reviews, 25(2013), ISSN:793-813

[3] Merwan Saad Saoud, Hadj Ahmed Abbassi, Saleh Kermiche,Mahdi Ouada, "Improved incremental conductance method for maximum power point tracking using cuk converter, WSEAS Transactions On Power Systems, Issue 3, Volume 8, July 2013, EISSN: 2224$350 \mathrm{x}$

[4] Chandani Sharma, Anamika Jain, "Solar Panel Mathematical Modeling Using Simulink", International Journal of Engineering Research and Applications", ISSN:2248-9622, Vol 4, Issue 5(Version 4), May 2014

[5] Muhammad H. Rashid "Power Electronics, Devices and Applications", 3rd ed.: Prentice Hall

[6] David San Morales, “ Maximum Power Point Tracking Algorithms for Photovoltaic Applications", Thesis for degree of Master of Science in Technology, 2010, Aalto University, School of Science and Technology

[7] Soedibyo ,Mochmad Ashari, Budi Amri," The Comparative study of Buck-Boost, Cuk, SEPIC and Zeta converters for maximum power point tracking Photovoltaic using P\&0 Method "Proc. of 2015 2nd Int. Conference on Information Technology, Computer and Electrical Engineering (ICITACEE), Indonesia, Oct 16-18th

[8] Ned Mohan, Tore M. Undeland, William P. Robbins, "Power Electronics, converters, Applications and Design", John Wiley and Sons, INC., Third Edition, 2003, ISBN:0-47122693-9. 